\title{
900 and Quadrante: Theorizing an Interdisciplinary Aesthetic Model
}

The metaphor of construction, and of the artist as constructor, enjoyed considerable currency in the Fascist period and marked many artists' and critics' vision of art and of the creative process (see Cioli 2011, 204-07; Salvagnini 2000, 30-32). Art critic Mario Tinti, for instance, had in 1927 heralded a 'new architectonic era' ('una nuova era architettonica'), calling for 'an art of the people, monumental and religious' ('un'arte del popolo, monumentale e religiosa') (cited in Salvagnini 2000, 30). The Fascist artist par excellence, Mario Sironi, took architecture and the figure of the architect as the subject of several of his paintings, and subsequently theorized mural painting (Sironi 1932; Sironi et al. 1933), establishing both an intellectual and a practical bond between painting and architecture. He conceived of the role of the artist in a collectivist society such as that envisioned by Fascism, as akin to that of a constructor, building on the solid cultural traditions of the nation, work and the family (Salvagnini 2000, 31; Pontiggia 1990). Our argument here, then, is that architecture and the novel intersected and developed in particularly close conjunction as intertwined aesthetic projects grounded in a set of common principles, and working to support the Fascist political project. In the journals 900 and Quadrante, they found two crucial platforms for expression and 
dissemination. The common principles they shared, as outlined in our first three chapters, were 'constructive' effort, the rationalization of aesthetic forms, the 'return to the real', the moral dimension of art, the establishment of a relationship between artists and the masses, and the collective and anti-individualistic meaning of art. The relationship between the novel and architecture under Fascism has received a certain degree of scholarly attention in relation to Bontempelli's thought (see Longatti 1969; Scarsella 1993; Tentori 1996; Storchi 2012; Sinopoli 2017). In this book, however, and in this chapter specifically, Bontempelli's crucial theoretical contribution is related to, and contextualized within, broader aesthetic projects which sought to establish structural links between the architectural and novelistic artistic fields with respect to their interaction with the Fascist regime. The chapter is divided into two sections. In the first section we will examine 900, before moving on to analyse Quadrante's programme in the second section, showing how discourses and debates on these journals constructed the novel and architecture as two deeply interconnected aesthetico-political endeavours.

Interaction between the arts was a cornerstone of Bontempelli's work and thought. Architecture and the novel held a privileged position in his interdisciplinary, inter-artistic paradigm. He saw literature as the 'substance of connection among all the superior activities of men' ('la sostanza di collegamento tra tutte le attività superiori dell'uomo'), the artistic form which provided men with the means to gain and express a comprehensive vision of human experience (from a speech pronounced in 1942, reprinted in Bontempelli 1945, 217, emphasis in original). This definition should be read in light of the centrality attributed by Bontempelli to the idea of unity, not only in the arts, but in human activities more generally, as he stated in the article opening the first issue of Quadrante:

The most interesting research that men can carry out by looking around themselves is the pursuit of unity. By this I mean unity of vision, and therefore of judgement. [...] Finding the centre from which one can see the movement of philosophical speculation, of artistic expression, of political action, of scientific curiosity, of the language of tradition, of everyday life-as one single harmonious fact. Unearthing its central rhythm. (Bontempelli 1933a) ${ }^{1}$ 
Crucially, this unity was also to be found in the synergy between aesthetics and politics, which Bontempelli regarded at this time as 'two facets of a unified human enterprise' (Rifkind 2012, 57). ${ }^{2}$ As he declared on the occasion of the debate on Critica fascista, discussed in Chap. 2, 'by "Fascism" we mean a whole orientation of life, public and private: a total and perfect order that is practical and theoretical, intellectual and moral, application and spirit' (Bontempelli 1926a, 416). ${ }^{3}$ He later identified this convergence of the aesthetic and political spheres as one of the defining principles of L'avventura novecentista: '[...] this unforeseen book documents a frame of mind prone to seeking harmony between the literary and the political spheres [...]' (cited in Jacobbi 1974, xiv). ${ }^{4}$

His interest in architecture largely derived from his belief in the intertwined nature of art and politics. In one of his most famous pieces on architecture, 'Architecture as morality and politics', he asserted that the reason why he was so passionate about a subject with which he was admittedly 'unfamiliar' was that

[...] it is not a question of architecture, it is not even a question of taste or aesthetics: it is a question of morality. The polemic around architecture is a profoundly political polemic. [...] An epoch reveals itself in all of its architecture. (Bontempelli 1933d, now in 1974 [1938], 334)

Architecture was an art form that embodied the spirit, values and morality of an era, and as such was necessarily political. Bontempelli also used it as a metaphor for the process of artistic creation, which needed to reflect the 'constructive' spirit of the new era. Accordingly, he very often referred to processes of artistic creation using the terms 'build(ing)' and 'construction', as will be shown in this chapter.

\section{0: Writing as Myth-Building}

The first issue of 900 came out in November 1926. It was initially published in French, with the title 900. Cahiers d'Italie et d'Europe. The title and choice of language are notable, in that they indicate an attempt at connecting and opening up Italian culture to Europe. ${ }^{6}$ Predictably, this 
choice attracted criticism, particularly, but not exclusively, from hard-line Fascist milieus. In an article published in the third issue, Bontempelli acknowledged that the 900 project had been criticized in Italy for being 'a shady enterprise of Europeanist internationalism' and in Europe for being 'a vigilant critic of voracious Italian imperialism' (Bontempelli 1927b, 163). ${ }^{7}$ Unsurprisingly, the seemingly contradictory position occupied by Bontempelli and his project-which proclaimed itself close to the regime and an advocate of a dominant and unmistakably Italian national art, but also, through its choice of language and its numerous international collaborations, clearly looked outwards to Europe-was the object of criticism from various quarters (Jewell 2008, 729; Gennaro 2010). ${ }^{8}$ After defending his position by claiming that opposed criticisms invalidate one another, Bontempelli restated the 'principal theoretical positions' ('principales positions théoriques') of the journal (Bontempelli 1927b, 164), which up until then had been presented in a rather piecemeal fashion in the preambles and elsewhere. This list of principles is a good starting point for an analysis of the theoretical programme proposed by the journal and of how it wove architecture and the novel together in its formulation of an aesthetic project alongside the political one. These principles included: the rejection of aestheticism and psychologism, seen as the degeneration of the classical and Romantic spirit respectively; the art of writing conceived as architecture, that is, the modification of the inhabitable world, which consisted in inventing myths and fables for the new era; the rejection of lyricism, metre and style; the rejection of orientalism and the formulation of a new idea of 'imagination' and the merveilleux (magic_-hence the name 'magical' or 'mystical realism'); the progression beyond the elitist spirit of the avant-garde in favour of a direct engagement with the masses; and the reinforcement of Italy's central position in the formation of a new Mediterranean culture.

These principles were the basis of a general effort of reconstruction and engagement with the real, particularly evident in the architectural and literary fields, which reacted against both the Romantic conception of art as an expression of personal feelings, and to the destructive spirit of the early twentieth-century avant-gardes. When applied to literature, powerful use was made of the parallel with architecture, which provided a productive metaphor and conceptual model through the idea of 'building 
things' and 'building stories'. The statement that opened the first issue and thus began the 'Novecento adventure' - naturally written by Bontempelli-was a declaration of the centrality of this idea to 900 's theoretical programme: 'The most urgent and precise task of the twentieth century will be the reconstruction of time and space' (reprinted in Bontempelli 1974 [1938], 9). Bontempelli clarified that this was the task of art, and not of philosophy: the palingenetic effort pertained to the creative and irrational human sphere, rather than to the rational one (see Chap. 2, p. 25). Bontempelli discussed this further in a commentary added in January 1928 and published in L'avventura novecentista. The task of what he called the 'Third Era', which was about to start (Bontempelli 1974 [1938], 13), was that of recovering the belief in the objectivity of the real, in the objective existence of an external universe outside and independently of Man. The underlying idea was that something objective existed beyond human consciousness and its subjectivity, necessitating a new relationship between the subjectivity of the artist and the object, the real. Space and time, the foundations of this universe, themselves needed to be reconstructed, because the 'previous era' had undertaken to destroy them and deny their existence. The reconstruction of time and space was the essential precondition for the 'recovery of the individual' ('ritrovamento dell'individuo'), a figure possessing a definite individuality and collective identity, and an awareness of their responsibilities and absolute morality, all of which democratic relativism strove to deny (Bontempelli 1974 [1938], 9, 27-28).

These theoretical premises show how inseparable 900's aesthetical project was from politics, and illustrate the nature of the interrelations between the two spheres. For the new idea of art advocated by the journal was indeed a reaction to aesthetic and political tendencies of the previous period, which were perceived as decadent and leading to inexorable moral decay. In the artistic sphere, these were aestheticism, that is, the myth of beauty and of art for art's sake, which had dismissed questions of art's morality; and impressionism, which had made the artist's fleeting personal impressions into an artistic ideal, preventing proper engagement with the real. In psychology, there was Freudianism, which had led to a loss of contact with external reality. In the political sphere, there was the 'democratic spirit' ('lo spirito democratico'), which validated any idea 
and tendency, without acknowledging the existence of an objective reality with its 'superior laws' ('legg[i] superior[i]') that should come before personal interests and convictions (Bontempelli 1974 [1938], 27-28). The principles of 900's 'new art' were defined in explicit opposition to these aesthetic and political tendencies. In his first 'preamble', Bontempelli emphasized the central role of architecture and of the architectural metaphor in his aesthetic paradigm, further developing the image of art as (re) construction. As well as the necessity of reconstructing space and time, he stated the need to 'learn the art of building things again, in order to invent the fresh myths from which a new atmosphere will originate, which we need in order to breathe' (Bontempelli 1974 [1938], 10).

Bontempelli's call to 'reconstruct reality' yet also 'invent myths' was only an apparent contradiction: the ultimate aim of the reconstruction of reality, of the 'solid world' ('mondo solido'), was to pace its boundaries and get to know it from the ground up in order to be able to modify it and shape it through art-again taking architecture as a conceptual model. Through this process, it would be possible to establish control over the external world, and finally 'subvert its laws' ('sconvolgerne le leggi')_ achieving what Bontempelli called 'magic' ('magia'), in an aesthetic project which he duly termed 'magical realism' ('realismo magico'). ${ }^{10}$ This process would culminate in the creation of modernity, which at that time only existed as a project, an object of the imagination; modernity was 'a subject yet to come, not fully actualized' (Buonanno 2003, 241), one which needed being built. This conception of art is clearly divergent from more conventional, mimetic forms of realism in that, here, reality must be interpreted and transfigured through the artist's imagination, rather than merely documented (Micali 2002, 93). This theorization of an art that could support the regime and build its culture, while not being openly political, was in line with the complexity and heterogeneity of the nature of the relationships between the regime and the arts discussed in Chap. 2 (see also Jewell 2008, 731). ${ }^{11}$

The fact that Bontempelli was concerned above all with literature, despite using the more generic term 'art', was implicit given the nature of the journal, which was essentially literary, with some space devoted to interdisciplinary reflections, discussion of other artistic forms (such as theatre and cinema), and even of non-artistic activities (such as boxing 
and motor racing). The journal's primarily literary focus became clearer in the theoretical discussions which appeared in the first few issues. The third preamble was entitled 'Consigli' and contained suggestions for writers (Bontempelli 1974 [1938], 17-21). An article entitled 'Mendicità' published in the fourth issue, in October 1928, emphasized literature's power to embody the spirit of its time, and hence its essential value in supporting an 'imperial' political project:

The old regime despised writers. I believe in the new regime there are a few politicians - two or three perhaps, and certainly one-who are willing to give literature the consideration it deserves. [...] By 'the consideration it deserves', I mean that literature is the highest expression of an age and at the same time its most delicate function. As such, it is the greatest ally of an epoch and of a project that wish to be called imperial. (Bontempelli 1974 [1938], 114-15) ${ }^{12}$

The idea of encapsulating the 'spirit' of the Fascist era was the key focus around which the whole debate about Fascist art revolved (see Chap. 2, section 'Defining Fascist Art'). Bontempelli believed literature to be an especially suitable art form to fulfil this ideal. He also believed that the regime - at least Mussolini- - had understood this, and had assigned literature and writers a new, central role, which contrasted with the alienation they had suffered under the liberal state. Writers should in turn not 'ask for protection' ('chiedere protezione'), but rather 'offer collaboration' ('offrire collaborazione'), carrying out their crucial function of supporting the Fascist project and educating the masses.

The theoretical programme of 900 was articulated mainly through Bontempelli's writings. However, the contributions of other authors were also crucial to its development. The writer Corrado Alvaro, for instance, was a regular contributor, and his articles were instrumental in defining the aesthetico-political agenda promoted by the journal. Two of his articles in particular merit discussion here: 'Letà della letteratura' (1926a) and 'La prosa' (1928). As is evident from the titles, Alvaro was, like Bontempelli, an advocate of the primacy of fiction, especially in its relation with history and politics. In these two articles, he proposed an idea of literature as the national art par excellence, the aesthetic practice that 
makes a nation, and therefore a fortiori creates reality. He understood literature as a 'social fact' ('fatto sociale') and a 'practical instrument' ('strumento pratico'), with a stronger connection with history and eloquence than with poetry. He situated the value of literature in its social function rather than in its lyrical content: literature, and fiction in particular, was able to create myths that forged national communities, and had historically fulfilled this purpose. Alvaro cited the example of Russia where, after suffering English and French cultural domination, people 'became typically Russian after an aesthetics of the Russian character was invented by writers' (1926a, 59). Literature therefore shaped the character of the nation and of its citizens, and 'the strength of a people consists in believing in the myths that are invented for them' (57). Thus, the novelist could 'invent' the spirit, sentiments and aspirations of a newand in this case Fascist-era, making them legible and real for all (Alvaro $1928,70)$. In an article entitled 'Moralità' (1926b), also published in the fifth issue, he reiterated this idea, calling for the construction of a new Italian civilization imbued with a new 'morality', through art.

It should be noted that, like Bontempelli, Alvaro made use of architectural metaphors to describe the type of literature that Italian society needed in this phase of its history:

Since the war, Italy has lived its first truly national life [...]. Slowly, the province becomes people, distinctive customs and characters disappear, psychological characteristics are reinforced [...]. If until yesterday the art of the Italian writer consisted in inventing social agglomerates based on foreign, and especially French models [...], today one only needs to look around to realize the immense subject matter that writers have under their noses. [...] It is natural that no poet of this transformation of classes yet exists. [...] Before the Baudelaires, we need those great builders of shared houses and castles in the air whose name is Hugo. (Alvaro 1928, 70-71) ${ }^{13}$

'National' novelists, who contribute to forging the spirit of a new era and building national myths, were evoked through the image of 'great builders of shared houses' which, among other things, recalled the debates and experiments being carried out in the field of social architecture at this time (see the second part of this chapter on Quadrante, and the section 
on the Olivetti factory, Chap. 7). These novelists were vital, and came before poets in the process of making a nation, just as Hugo had come before Baudelaire in France.

\section{Architecture as a Conceptual Model}

Bontempelli articulated his theorization of a new literature through the metaphor of architecture, proving how he conceived of the two artistic forms as bound together in a structural and conceptual relationship. In his aesthetic model, 'the feminine aspiration to the condition of music will make way for the virile laws of architecture' ('l'aspirazione femminile alla musica farà luogo alle leggi virili dell'architettura'), 'music' being the lyrical, Romantic, impressionist element of literature, and 'architecture' being its element of construction, connected to the 'art of narrating' ('l'arte del narrare') (Bontempelli 1974 [1938], 10). ${ }^{14}$

New literature would therefore be anti-lyrical and anti-Romantic. Logically, this theoretical principle led to a predilection for fiction over poetry: 'As far as literature is concerned, we will see the work of fiction come to the fore, especially fiction based on invention and storyline' (Bontempelli 1974 [1938], 16). ${ }^{15}$ To describe this process of artistic creation, which had as its ultimate aim the creation of myths, the metaphor of the work of the architect was used:

Once we have placed a new solid world before us, our most pressing task will be to pace around it and explore it; to carve blocks of stone from it and place them one upon the other to put up weighty constructions, relentlessly modifying the shell of the earth we have reclaimed. (Bontempelli 1974 [1938], 10) ${ }^{16}$

This conception of literature, grounded in the predominance of the storyline and the aspiration to 'invent myths', was opposed to the artistic ideal based on the artist's subjectivity, sensations, and the supreme value of introspection that had hitherto prevailed (see Chap. 3). Among his suggestions for writers in the third preamble, Bontempelli included the recommendation to 'learn the ropes' in a newsroom, by practising turning 
news snippets into stories able to engage readers (Bontempelli 1927a, reprinted in 1974 [1938], 17).

In a later article, he developed this idea into a comparison between the writer-journalist and the architect-engineer, emphasizing the primary importance of 'craft', namely the ability to tell stories for a writer, and to design functional buildings for an architect (Bontempelli 1974 [1938], 55-56). In his view, every architect first had to be an engineer, just as any writer first had to be good at crafting stories. ${ }^{17}$ The widespread belief in a separation of such a 'technical' element, from the 'artistic' element of the work of the literary author and the architect, was what had caused the decline and failure of these arts, visible in their withdrawal from society and the public. Bontempelli called the 'new' writer a functional writer, establishing a connection with what at the time was called-albeit with derogatory intent - 'functional architecture', following the principle of construction for utility and rejecting the idea of architecture as decoration (see the section below on Quadrante). The main quality of a functional writer was to 'write in order to communicate something to the public' ('scrive[re] per comunicare qualche cosa a un pubblico') (Bontempelli 1974 [1938], 56): this writer-journalist would also, therefore, bring art back to its social function.

The need to re-establish a connection with the public, in particular a mass public, was clearly a cornerstone of Bontempelli's aesthetic programme. While part of a wider reflection on the role of artists in modern society (see the section on the novel 522 in Chap. 7), the need for engagement with a mass public reflected the regime's efforts more generally towards popularization in the artistic and cultural sphere. It was also in explicit opposition to the 'non-communicative writing' ('scrivere incomunicativo') (Bontempelli 1974 [1938], 56, footnote) of the disengaged, bourgeois and Romantic man of letters. In 1936, Bontempelli wrote that the only art worthy of the name is 'communication' ('comunicazione'), which necessarily entails a political dimension; therefore, any work that has artistic value also has political value (Bontempelli 1974 [1938], 207). It is worth placing Giuseppe Pagano's words alongside Bontempelli's, in order to appreciate the extent to which these projects for the reconstruction and modernization of Italian architecture and the Italian novel converged, sharing the idea of the moral and social function of art as one of their central founding principles: 
Modern architecture means, first and foremost, architecture made for men belonging to contemporary civilization. It means architecture that is morally, socially, economically, and spiritually tied to the conditions of our country. It means building in order to represent a people's civilization, to meet their needs, to 'serve' in the real sense of the word. It is essential to get it into our heads that every architectural work must submit itself to this utilitarian slavery. (Pagano 1935, reprinted in 2008 [1976], 31-32) ${ }^{18}$

The synergy between the two projects was acknowledged explicitly by Bontempelli in a comment presumably written when he assembled these writings in L'avventura novecentista, where he established a connection between the notion of 'mestierantismo' (a term, normally used disparagingly, referring to an emphasis on craftsmanship) and that of functionalism, already embraced by architecture. He then commented that this tendency, together with other common points, inevitably led to a 'close alliance [of the new novel] with functional architecture' ('una stretta alleanza' [del romanzo nuovo] con l'architettura funzionale') (Bontempelli 1974 [1938], 63, footnote).

One of the supreme aesthetic qualities extolled by Bontempelli in his programme for the modernization of the novel was 'anonymity'; again, a quality possessed chiefly by architecture (see analysis of buildings in Chap. 7). The architectural metaphor was thus continued in the theorization of an anonymous, anti-subjective art, detached from the artist's individuality:

The important thing is to create objects to place outside of us, detached from us: and through them, modify the world. [...] This is the spirit of architecture. Architecture rapidly becomes anonymous. Architecture reshapes the surface of the world in its own way [...]. Poetry must do the same [...]. (Bontempelli 1974 [1938], 15) ${ }^{19}$

Bontempelli alluded to how works of architecture naturally reveal very little of the subjectivity of their creator, of how they easily become 'common property', almost 'things of nature', and he urged writers to apply the same ideal of artistic creation to literature. An 'anonymous' art conceived in this way could perform the task that the regime expected from writers: creating artistic works that would become part of, and con- 
tribute to build, a collective heritage, thus fulfilling a social role. Bontempelli reiterated this idea in his third preamble, 'Consigli': 'The supreme ideal of all artists should be to become anonymous' ('Lideale supremo di tutti gli artisti dovrebbe essere: diventare anonimi) (Bontempelli 1974 [1938], 19, emphasis in original). In order to clarify this statement, he recounted an anecdote about Italian writer Alessandro Manzoni, the author of the historical novel The Betrothed (1840-42), foundational to Italian culture and language. One day, Manzoni visited one of the towns of 'that branch of the lake of Como' that compete for the honour of having served as a model for the town in The Betrothed. There the author met a peasant, who offered to direct him towards the famous house of the protagonist of his own novel, Lucia. After asking him some questions, the writer realized that the man was not aware of the existence of a novel entitled The Betrothed, or even of a novelist called Alessandro Manzoni, despite clearly being very familiar with, and personally engaged by, the story.

Thus, Bontempelli theorized a model of fictional writing that would not have as its purpose the expression of the inner reality or the individual genius of the author, but rather the creation of a 'reservoir' of fables and myths that would educate the masses through the production of a collective imagination, with the encouragement of the regime. Again, it is worth comparing this with Pagano's parallel thoughts on 'anonymity' in the field of architecture, in which he too, interestingly, used words borrowed from the literary field to describe the creative process:

If we want Italian architecture to proceed along a path capable of moral and aesthetic development and if we want to express our world, we need to act and think and compose poetry [poetare] not with an aristocratic, eccentric sensitivity, proudly enamoured of ratiocinative speculation, but rather aspire to be anonymous, to be free of rhetorical attitudes, and not imprison ourselves in an academy of forms and words. (Pagano 1937, reprinted in 2008 [1976], 150) ${ }^{20}$

The necessity of relinquishing individualism in favour of collective labour, realized in collaborative projects and buildings responding to social needs and functions, and in anonymous architecture, was also a tenet of the 
modern movement, and was included in the Manifesto of the rationalist Gruppo 7, many of whose members later became involved in the Quadrante project (see the section on buildings in Chap. 7).

\section{Quadrante: A 'United Aesthetic Front' for the Modernization of Fascist Culture}

The 'close alliance', as Bontempelli called it, between functional architecture and the new novel was cemented in the pages of Quadrante. The first issue of the journal, published on 1 May 1933, opened with two articles written by its two directors, Bontempelli and Pietro Maria Bardi. Bardi stated that

[i]t was inevitable that I should undertake a close collaboration with Bontempelli. The decisive contribution he made to the polemic I started in favour of rational architecture is unforgettable [...]. That was how we, the new architects and I, found a common understanding with Bontempelli, exploring conditions and clarifying ideas regarding the necessity of something like a united aesthetic front. (Bardi 1933a, 2) ${ }^{21}$

The correspondence preceding the launch of Quadrante, in which the two directors discussed the contents and slant of the journal, particularly its first issue, reveals the intellectual continuity that they sought to establish between 900 and Quadrante. ${ }^{22}$ From a letter of January 1933, we gather that Bontempelli's original idea was to call the journal Quadrante '900, and that if it was decided that it should be named simply Quadrante, he wanted an article in the first issue explaining why it was not called 900. The reason was that the words '900' and 'novecentista' had been appropriated by artistic movements with which the Quadrante group did not wish be associated, particularly in the field of architecture, a crucial focus of the magazine (Tentori 1990, 370-71). Indeed, compared to 900, Quadrante significantly shifted its focus towards architecture, specifically rational-functional architecture, which Bardi in particular aimed at establishing as the arte di stato of the Fascist regime (Bardi 1931a). 
Quadrante played a key role in the establishment of rationalism, the Italian 'variant' of modernist architecture, and in its politicization, as shown by David Rifkind in his seminal monograph (2012). However, the journal played another crucial role in 1930s' Italian culture, namely that of establishing a platform for the creation of an interdisciplinary project of cultural renewal under the auspices of the Fascist regime. In this regard, it is useful to mention that neither Bardi nor Bontempelli were architects. One of the main principles behind the creation of Quadrante was the ideal of the 'unity' of the arts, as clearly stated by its directors in the first issue. Accordingly, one of its main goals was the formation of what Bardi called a 'united aesthetic front' ('un fronte unico dell'estetica'). This could be defined as a united front of aesthetic modernity, engaging not only in a 'battle for modernism', but also in a battle for modernity - understood as a specifically Fascist and interdisciplinary aesthetic modernity-which would result in the renewal of the cultural and social spheres through the arts. According to Jeffrey Schnapp,

[Quadrante] set out to interpret the word 'architecture' in the broadest possible sense: as referring to the entire complex of means by which an ultramodern fascist Italy - a technologically, socially, culturally, juridically, politically, and psychologically modernized Italy-could be constructed. (Schnapp 2004, 37)

This endeavour was alluded to by Bardi in his first editorial, when he talked of Quadrante as a 'meeting place of unfettered, advanced, and original intelligence' ('un centro di ritrovo per un'intelligenza spregiudicata, avanzata, originale') (Bardi 1933a, 2). ${ }^{23}$ Even the leading rationalist architect Terragni, who was involved in the preliminary discussions on the contents of the journal, as well as contributing financially to its publication (Rifkind 2012, 15), defined Quadrante as a 'journal of battle, which must represent and unite all the healthy and reliable forces of the squadristi of the new architecture, painting, sculpture, literature'. ${ }^{24}$ The word 'squadristi' evoked two key features of Quadrante: the idea of 'battle' as the driving force behind the project (Rifkind 2012, 65), and its complete and militant endorsement of the regime. As Rifkind puts it, the architects, writers and intellectuals involved in the project 'enthusiastically 
supported the Fascist regime, and saw in Mussolini's "revolution" an analogue to the revolutionary project of modern architecture' $(2012,62)$. Bardi spelt this out clearly in his opening article:

Faced with so much confusion, so many compromises, so much avoidance of a thorough and honest examination of the question, crucial to us, of an adjustment to the present and a participation of art to life (and by life we mean Mussolini's Revolution as a spiritual guideline and a synthesis of action and thought), we believe that "Quadrante" will have a useful function. [...] We are Fascists above all. (Bardi 1933a, 2) 25

Quadrante thus set out to promote an art that was modern (adapted to the present) and directly engaged with the regime, encompassing both action and thought. The idea of reconstruction that underpinned 900 's programme, in tandem with the political action of the regime, was reaffirmed even more forcefully as a cornerstone of Quadrante. In a short commentary ('Corsivo n. 1') placed prominently in the first issue, straight after the 'Principles' and a reprint of Mussolini's 1919 presentation of the journal Ardita, Bontempelli declared that 'In ten years, Fascism has rebuilt a politics and a morality for Italy. In ten more years, we want to rebuild its art and philosophy' (Bontempelli 1933b). ${ }^{26}$

\section{Where Literature and Architecture Intersect}

In his opening editorial, Principii, Bontempelli wrote that 'today [...] the expressive centre of our life is architecture' (Bontempelli 1933a, reprinted in Bontempelli 1974 [1938], 75), reaffirming architecture as the crux of an interdisciplinary paradigm of aesthetic modernity, and a metaphor for a necessary renewal of the processes of artistic creation, of engagement with the public, and of the place of the arts in a modern society (see Storchi 2012). He qualified the architecture 'that matters' ('che conta') with the adjectives 'rational' ('razionale') and 'functional' ('funzionale'), and gave a definition of this new interdisciplinary aesthetic modernity which was premised on the deliberate intermingling of images drawn from the fields of architecture and the novel: 
The maximum of expression, the minimum of gesture, terror of the slow, decline of repose, to build without adjectives, to write with smooth walls, beauty intended as necessity, thought born as risk, the horror of the contingent. (Bontempelli 1933a, emphasis in original) ${ }^{27}$

This definition points to an identification of the aesthetic value of an artwork with its functionality, a mainstay of the rationalist architectural programme (De Seta 1998, 126), which, as we have seen, had been theorized in relation to the 'new novel' by Bontempelli in 900. This principle of modern architecture and literature would be followed through the rationalization of aesthetic means in both architecture and the novel. The opening article of Quadrante thus put forward the ideas of rationalization and functionality as the principles of an aesthetic modernity that would build the regime's arte di stato, hinging in particular on an alliance between architecture and the novel.

Significantly, the subsequent pages were occupied by writings focusing on literature and architecture, thus establishing a conceptual framework grounded in the intersection between the two artistic forms. In the article 'Tradimento', writer and intellectual Marcello Gallian emphatically championed an anti-bourgeois, worthwhile art directed at the masses and close to everyday life: 'a useful literature, whose beauty lies precisely in its practical worth' ('una letteratura utile e bella appunto per quell che vale') (Gallian 1933, 4). Immediately afterwards came an article by writer Francesco Monotti, eloquently entitled 'Antiletteratura', which also strongly advocated a popular, socially meaningful and moral literature, engaging with the real and with the masses. The notion of 'anti-literature' had already been introduced by Bontempelli in 900, where it was defined as one of the 'fixations' ('fissazioni') of the 900 movement (Bontempelli 1927c). This expression conveys the extent to which these intellectuals and artists conceived of the new literature as breaking with dominant literary traditions and conventions. ${ }^{28}$ Monotti argued that literature in Italy had never been popular because it had always lacked contact with the masses, which constitute literature's real lifeblood. Art, and above all literature, must consist of action and exist in a direct, unmediated relationship with reality: this was its 'antitoxin' ('antitossina'), the antidote against the rampant corruption affecting literature. 
Writers needed a direct relationship with reality because reality was, and had to be, the subject matter of their works. Monotti bemoaned the paradox whereby novels were full of 'common figures' like engineers, 'every sorts of maker' ('costruttori d'ogni specie') (and it is significant that he chose to mention engineers and makers drawn from all professions), but also less prestigious figures like servants and clowns, and yet these categories of people were not acquainted with literature, and if they were, they distrusted it. The fault did not lie with the public who had abandoned literature, but with the writers, who did not appeal to the wide public and therefore had lost their trust and interest.

According to Monotti, in order to correct this situation authors had to go back to the essence of life and to its 'elementarity' ('elementarietă), a word of which Bontempelli was fond (see Bontempelli 1974 [1938], 336 , for instance). In line with the journal's programme, he thus stated the need for a rationalization and simplification of literary languages and themes, a precondition for establishing the necessary relationship with the masses. This engagement with reality and the inextricable ties linking literature with life and with action would bring about moral renewal in literary works, expressed in the celebration of the essential things that mattered in life. This was an urgent message, central to the Fascist revolution, which writers had not hitherto embraced. As Monotti put it, a soldier or a squadrista who died fighting could teach everyone the true value of life, and novels should have the same power and moral impact. The arts under a totalitarian regime like Fascism, which aimed to shape all aspects of social life, were expected to embody and convey its values, therefore literature had to start embodying the principle of moral essentiality. A direct experience of reality was crucial to this process: the writer, like everyone else, had to be a man of action and 'get his hands dirty' ('sporcarsi le mani'), because only someone who had done something could have something valuable to tell (Monotti 1933).

The pieces following Monotti's article reprised the same ideas in relation to architecture. 'Un programma d'architettura', signed by most of the rationalist architects involved in the Quadrante project and echoing the manifesto of the Gruppo 7 (Rifkind 2012, 63), stated as its fourth principle the need for the 'moral act' ('fatto morale') and a moral consciousness to coexist alongside the 'artistic act' ('fatto artistico'), as a 
measure of the value of an artist. ${ }^{29}$ The sixth principle affirmed that 'classicism' and 'mediterraneitä' were specific features of Italian rationalism, in contrast to 'Northist', Baroque, or Romantic tendencies. These distinctive traits were to be manifested not in the form, but rather in the spirit of new architecture, which signified an effort towards rationalization, clarity, and order. ${ }^{30}$ Italian rationalism was identified as 'linear' and 'intransigent' ('lineare e intransigente') (Bottoni et al. 1933). The following article, 'Significato estetico del razionalismo', written by architect Giuseppe Pensabene, emphasized the need for rationalist architecture to re-establish an adherence to the real, and criticized formalism which, by focusing on the quest for perfect forms and on the 'conversation' among these forms, had lost this crucial contact with reality. His reflections echoed Bontempelli's thoughts on the primary importance of the writer's engagement with reality, first published in 900, which theorized a new relationship between objectivity and subjectivity as a founding principle of Fascist art.

Pensabene propounded an anti-aesthetic and anti-decorative stance, stating that the value of a building could only be measured by looking at its spatiality. The monodimensional aesthetic idea of the 'façade' was antiarchitectural, insofar as it was scenographic and purely ornamental, whereas architecture was '[...] an immensely more complex art which engages with the real in much more profound ways' (" $[. .$.$] arte immensa-$ mente più complessa e implicante ben altrimenti il reale') (Pensabene 1933 , 6). This spatial, multidimensional conception of architecture, engaging in a complex relationship with reality, was tellingly qualified as 'totalitarian' ('totalitaria'), while non-totalitarian architecture was compared to a 'stage-set' ('una scena'), a 'limited conception of life' ('una concezione ridotta della vita'), something 'fragmentary' ('frammentario') and lacking a direct relation with reality. A connection had to be established between art and life: architecture achieved this by 'superimposing itself on reality' ('sovrappone[ndosi] al reale') (Pensabene 1933, 7). We are reminded, again, of Bontempelli's invective against the idolization of the 'fragment' in literature and the 'folly of the invention of the pseudo-fragment' ('la follia dell'invenzione dello pseudoframmento') (Bontempelli 1928). The aesthetic precepts of Sartoris and Bontempelli intersected in their advocacy of the pursuit of 'totality' through art-as 
opposed to an aesthetic of the fragment - in the fields of architecture and literature (see section on 'The Total Work of Art', Chap. 4). Finally, Sartoris reiterated one of the central theoretical tenets proclaimed by the journal, namely, the need for the rationalization of forms coupled with functionalism, when he imagined '[...] great smooth surfaces whose beauty will lie in the revelation of their purpose' ('[...] grandi superfici liscie, la cui bellezza sarà nella rivelazione del loro scopo') (Pensabene $1933,7)$. The notion that a building's aesthetic value lay in its functionality was reaffirmed as the core principle of rationalist architecture: 'only in the progression beyond the dualism between utility and beauty is it possible, today, to distinguish the principle of new architecture' (Ibid.). ${ }^{31}$

The second issue of Quadrante opened with the reproduction of a speech delivered by Mussolini at the Teatro Argentina, in Rome, on the occasion of the fiftieth anniversary of the Società degli Autori (Mussolini 1933). After addressing the question of theatre for the masses, Mussolini shifted his focus to the novel, defining it as 'a powerful instrument for the education of the people' ('uno strumento possente dell'educazione del Popolo') (1933, 2). He praised those contemporary Italian writers who were 'powerful, robust in form and rich in thought' ('potenti, solidi nella forma e, ricchi di pensiero'), evoking, albeit in vague terms, the type of novel theorized by the 900 group (ibid.). He also declared his complete confidence in 'the forces of the Italian spirit and intelligence' (Ibid.) ${ }^{32}$ and acknowledged that, if the State cannot create its own literature, it can support its writers and nurture their creative endeavours, publicly stating one of the main principles of Fascist cultural policy (see Chap. 2, 17-18). In a commentary on this speech, Bontempelli expressed his belief that fiction would be the most distinctive artistic form of the twentieth century, and one in which Italians would prove their talents. He reaffirmed the centrality of the social function of art in the Fascist era, sanctioning the end of the avant-gardes, if by avant-garde one meant speaking an elitist artistic language directed at the happy few. The new avant-garde, in the sense of modernity, would have to speak to the masses and have something new to tell them, following the example set by the Fascist regime in the political sphere (Bontempelli 1933c). ${ }^{33}$ The next article was Bardi's 'Considerazioni sulla Triennale', 34 which contained very similar ideas applied to the field of architecture. Bardi criticized the 'bourgeoisification' of the Triennial, manifested in the build- 
ing and exhibition of several houses ('villini) destined for the urban bourgeoisie. Bardi argued that the era of the bourgeois house was over, and that the representative architecture of the Fascist era would consist of 'social houses, barracks, hospitals, case del Fascio, institutes of the regime' (1933b, 6). ${ }^{35}$ In short, architecture would embody Fascist values through modern, functional buildings meant for the collective use of public space and for the articulation of the relationship between the State and the masses (see the analysis of buildings in Chap. 7). Indeed, the renewal of architecture was to be brought about through 'constructions for popular use' ('costruzioni popolari e d'uso popolare'), and therefore architectural exhibitions, too, had to 'move towards the people' (Bardi 1933b, 6, emphasis in original). ${ }^{36}$

Bontempelli echoed these ideas in an article published a few months later, this time not in Quadrante, but in the Fascist newspaper Gazzetta del Popolo, in which he once again placed architecture and the novel side by side as the two artistic forms most thoroughly engaged in the construction of an art for the Fascist era-an art which should be popular, functional, rationalized and collective. Architecture was able to embody the spirit of an era, and the Fascist era could not be represented by bourgeois houses, but only by 'utilitarian' buildings ('costruzioni [...] "utilitarie"') and works 'destined for the collectivity' ('opere di destinazione collettiva') (Bontempelli 1933d, reprinted in 1974 [1938], 335). While the bourgeoisie would not understand this new art, the 'common people' would, because they were used to equating beauty with simplicity, and with objects whose form followed their purpose. Literature was, according to Bontempelli, the only art that alongside architecture, had started a process of renewal based on these principles, and the best Italian literature revealed 'worthy efforts in the pursuit of a superior simplicity in its means, and a profound elementarity in its substance' (Bontempelli 1974 [1938], 336, emphasis in original). ${ }^{37}$ The other arts should follow the example set by architecture and literature and begin 'creating [...] spacious constructions for the collective life of simple souls' ('creare [...] ariose costruzioni per la vita collettiva degli animi semplici') (Ibid.).

The notions of morality, essentiality and rationalization were thus tightly interrelated in the narrative woven by 900 and Quadrante, binding the artistic and political spheres together. These were the principles 
upon which the regime based the relationship between the State and the individual, in order to bring about an anthropological revolution. The arts, as we have already argued, were a crucial part of this process. Thus, these were also the principles on which the arts, in particular architecture and the novel, should be based, in order to perform a social function of educating the masses and framing them within the structures of the State. The eighth issue of Quadrante opened with an article written by Bottai, entitled 'Totalità, perennità, universalità della rivoluzione fascista' which significantly entered into dialogue with the aesthetic-political programme promoted by the journal. In examining the threefold nature of the Fascist revolution, Bottai observed that Fascism was a totalitarian project, as it sought to be actualized in all aspects and spheres of the national life. As a result of the actualization of the revolution, the citizen of the Fascist state would be 'totally engaged, in his faith and interests, in his consciousness and in his profession, by a superior rule of order and unity [...]' (Bottai $1933,1) .{ }^{38}$ This same superior law was, or should be, embodied by the new literature and the new architecture. The Fascist revolution was a revolution of the spirit, and not simply a legal or political change. It was a 'movement [...] spread across the moral atmosphere of our time, carrying out a broad revision of values and principles' (Bottai 1933, 2). ${ }^{39}$ These same principles and values would be expressed in Fascist novels and buildings, the guiding essence of which was morality. Architecture and literature were thus conceived of not as a means for the expression of the subjectivity of the individual artist, but as spaces for the creation of a collective morality supporting the Fascist revolution, which would manifest itself aesthetically in the rationalization of languages and forms.

\section{Notes}

1. 'La ricerca più originale che l'uomo possa fare guardandosi attorno nel proprio tempo, è la ricerca dell'unità. Si vuole intendere: unità di visuale, e perciò di giudizio. [...] Trovare il centro donde si veda il muoversi della speculazione filosofica, della espressione artistica, dell'azione politica, della curiosità scientifica, del linguaggio, del costume della vita d'ogni giorno — come un solo fayyo armonioso. Scovarne il ritmo centrale.' 
2. We are referring here to the years when 900 and Quadrante were published, between 1926 and 1936, a period in which the regime had the support of large sections of the Italian artistic and intellectual milieus. Bontempelli was involved with Fascism well into the 1930s. His engagement was not strictly artistic, and included being secretary of the Fascist writers' corporativist union for several years in the late 1920s. His support began wavering during the 1930s, but it was not until 1938 that he fell out with the regime, like many other artists and intellectuals. See Jewell 2008 for further details, and for a discussion of the relationship between Bontempelli's magical realism and Fascist activism.

3. '[...] per Fascismo noi indichiamo tutto un orientamento della vita, pubblica e indivuale: ordinamento compiuto e totale, cioè pratico insieme e teorico, intellettuale e morale, applicazione e spirito'. Translation by Barbara Spackman, Jennifer Roberts, and Elizabeth Macintosh (Schnapp 2000, 218).

4. '[...] questo libro inopinato documenta uno stato d'animo incline a cercare armonia tra il letterario e il politico [...].' L'avventura novecentista is a volume assembled and edited by Bontempelli in 1938, collecting writings published between 1926 and 1938, including the 'preambles' and other important articles published in 900. As the title suggests, it reconstructs the trajectory of the Novecento movement.

5. '[...] non è una questione di architettura, non è neppure una questione di gusto e di estetica: è una questione di ordine morale. La polemica intorno all'architettura è una polemica profondamente politica. [...] Un'epoca si rivela tutta in tutta la sua architettura.'

6. On the journal's Europeanist aspirations, see Mancini 2004 and Gennaro 2010.

7. 'Des adversaires italiens ont dénoncé «900» comme étant une louche entreprise de l'internationalisme européiste. Des adversaires étrangers ont prêté serment que «900" est une redoutable patrouille du vorace impérialisme italien.'

8. Bontempelli justified this choice stating that 900 aimed at spreading 'Italian values' abroad, and in order to do that, it needed to be written in a language widely understood in Europe (Bontempelli 1926b; see also Gennaro 2010).

9. 'Occorre riimparare l'arte di costruire, per inventare i miti freschi onde possa scaturire la nuova atmosfera di cui abbiamo bisogno per respirare'. 
10. For further discussion of magical realism, see the analysis of Bontempelli's novel 522 in Chap. 7.

11. Like many artists and intellectuals in this period, Bontempelli repeatedly declared that a Fascist artwork was not an artwork about Fascism. For instance: '[...] in a hundred years' time a purely fantastic novel could appear to be more representative of the Fascist spirit than one that stages the March on Rome' ('[...] tra cento anni un romanzo di pura fantasia potrà apparire aderente allo spirito fascista assai più di uno ove si metta in scena la Marcia su Roma') (1929, now in 1974 [1938], 213).

12. 'Il vecchio regime disprezzava il letterato. Credo che nel nuovo regime ci siano alcuni politici-due o tre forse, certamente uno-disposti a tenere la letteratura nel conto che merita. [...] Per "il conto che merita", intendo che la letteratura è la più alta espressione d'un tempo e però la sua più delicata funzione. Come tale, essa è la grande collaboratrice d'un epoca e d'una azione che vogliano chiamarsi imperiali'.

13. 'L'Italia vive dalla guerra in poi la sua prima vita veramente nazionale [...]. Lentamente la provincia diventa popolo, spariscono i costumi e i caratteri esterni, si rafforzano i caratteri psicologici [...]. Se fino a ieri l'arte dello scrittore italiano era quella di invenatre agglomerati sociali sullo stampo di quelli stranieri e generalmente francesi, [...] oggi basta guardarsi intorno per accorgersi che materia immensa ha sotto gli occhi uno scrittore. [...] È naturale che non esista un poeta di questa trasformazione di classi. [...] Prima dei Baudelaire ci vogliono quei grossi costruttori di case popolari e di castelli in aria che si chiamano Hugo.'

14. It is interesting to compare this statement with the use of a similar metaphor, albeit to support a diametrically opposed argument, by architect Marcello Piacentini, in one of his earliest attacks against rationalist architecture: 'Why then this need to make the entire essence of architecture consist of rationality alone? [....] The identification of beauty with structure does not exist. Let us leave these dry metaphysical speculations to the people of the North. Neither puritanism nor Protestantism have ever taken root under our sun. We need gesture and form; the moving word and a smile. We are essentially musical; art, for us, is always a song.' ('Perché, insomma, voler far consistere tutta l'essenza dell'architettura nella sua razionalità? [...] L'identificazione del bello con lo strutturale non esiste. Lasciamo queste speculazioni aride e metafisiche agli uomini del Nord; sotto il nostro sole non ha mai attecchito il puritanesimo, né il protestantesimo. Noi abbiamo bisogno del gesto e della forma; della parola com- 
mossa e del sorriso. Noi siamo essenzialmente musicali; l'arte per noi è sempre un canto.') (Piacentini 1928, reprinted in Patetta 1972, 158).

15. 'Quanto alla letteratura, vedremo avanzarsi al primo piano l'opera narrativa, quella specialmente che si fonda sull'invenzione e sull'intreccio.'

16. 'Quando avremo collocato un nuovo solido mondo davanti a noi, la nostra più solerte occupazione sarà passeggiarlo ed. esplorarcelo; tagliarne blocchi di pietra e porli uno sopra l'altro per metter su fabbricati pesanti, e modificare senza tregua la crosta della terra riconquistata.'

17. The figure of the engineer was central to the revolutionary ideas of the avant-gardes in the first half of the twentieth century, especially, but not only, in the field of architecture (see Schnapp 2004, 1-5). The engineer was widely celebrated as the 'guarantor of an immediate linkage between art and life, as embodying the new norm to be followed by less technically proficient practitioners of thought or art, and as an ideal agent of rationalization and democratization' (Schnapp 2004, 1).

18. 'Architettura moderna significa anzitutto architettura fatta per uomini appartenenti alla civiltà contemporanea; significa architettura moralmente, socialmente, economicamente, spiritualmente legata alle condizioni del nostro paese; significa costruire per rappresentare gli ideali del popolo, per soddisfarne i bisogni, per "servire" nel vero senso della parola. È necessario mettersi bene nella testa che tutte le opere di architettura devono sottoporsi a questa schiavitù utilitaria.'

19. 'L'importante è creare oggetti, da collocare fuori di noi, bene staccato da noi; e con essi modificare il mondo. [...] È lo spirito dell'architettura. L'architettura diventa assai rapidamente anonima. L'architettura rifoggia a suo modo la superficie del mondo [...]. Lo stesso deve fare la poesia [...].'

20. 'Se vogliamo che la letteratura italiana proceda entro una strada capace di sviluppi morali ed. estetici e se vogliamo esprimere il nostro mondo, è necessario agire e pensare e poetare non con sensibilità aristocratica, eccentrica o superbamente innamorata della speculazione raziocinante, ma desiderare di essere anonimi, di essere puri da atteggiamenti retorici, di non volerci noi stessi imprigionare in un'accademia di forme e di parole.'

21. 'Era fatale che con Bontempelli dovessi realizzare una stretta collaborazione. Il decisivo ausilio che egli ha dato traverso alcuni suoi scritti alla polemica da me intrapresa in favore di una architettura razionale, è indimenticabile [...]. Fu così che noi, io e gli architetti nuovi, ci intendemmo 
con Bontempelli in fraternità, scoprendo alcune circostanze e chiarendo alcune idee sulla necessità di costituire qualche cosa come un fronte unico dell'estetica.'

22. The correspondence is published in Tentori 1990, 365-77.

23. Translation by Rifkind $(2012,15)$.

24. '[...] una rivista di battaglia, che dovrà rappresentare e riunire tutte le forze sane e collaudate deagli squadristi della nuova architettura, pittura, scultura, letteratura'. Fondo Carlo Belli, Archivio del '900, MART. Letter from Terragni to Belli, 4 December 1931.

25. 'Tra tanta confusione, tra tanti accomodamenti, tra tanta rinuncia verso un esame pieno e franco della questione per noi cardinale d'un adeguamento ai tempi e della partecipazione dell'arte alla vita (e si intende per vita intanto la Rivoluzione Mussoliniana come direttrice spirituale e come sintesi d'azione e di pensiero) noi riteniamo che "Quadrante" avrà una funzione noninutile. [...] noi siamo fascisti prima di tutto.'

26. 'In dieci anni il Fascismo ha ricostruito all'Italia una politica e una morale. In altri dieci anni vogliamo ricostruirle un'arte e una filosofia'. Translation by David Rifkind $(2012,55)$.

27. 'Il massimo della espressione, il minimo di gesto, terrore del lento, disprezzo per il riposo, edificare senza aggettivi, scrivere a pareti lisce, la bellezza intesa come necessità, il pensiero nato come rischio, l'orrore del contingente'. This well-known passage first appeared in an open letter addressed by Bontempelli to Bardi, published on La Gazzetta del popolo on 25 June 1932. Translation by David Rifkind $(2012,57)$.

28. The concept of 'anti-literature' was widespread in Fascist Italian literary culture. For instance, it was one of the tenets of the ideal of literature championed by the journal I lupi, where it signified the (paradoxical) 'disgust for words', and the 'esteem for the fact' and 'the concrete thing' (Napolitano 1928, quoted and translated in Ben-Ghiat 1995, 644; see also Ben-Ghiat 2001, 56).

29. The signatories were Piero Bottoni, Mario Cereghini, Luigi Figini, Guido Frette, Enrico A. Griffini, Piero Lingeri, Gino Pollini, Gian Luigi Banfi, Lodovico B. di Belgioioso, Enrico Peressutti, and Ernesto N. Rogers. Giuseppe Terragni, who had contributed to the foundation of Quadrante, was notably absent. According to Rifkind, this might be due to his brief disagreement with the other Quadrante members after they decided to exclude architect Luciano Baldessarri from the project (Rifkind 2012, 65). 
30. As noted by Rifkind, 'spirit' and 'morality' were central concepts in the theories and programmes of Italian rationalists, but were never clearly defined $(2012,64)$. This was in line with a common tendency of Fascist discourse, which also marked the field of aesthetics (see Chap. 2, p. 24). According to Rifkind, 'the rhetoric of morality conveyed the idea of deeply held (rather than opportunistic) beliefs that were above criticism' (Ibid.), echoing the 'superior laws' governing reality in Bontempelli's thought (1974 [1938], 27).

31. 'Solo nel superamento del dualismo tra utilità e bellezza, è possibile, oggi, intravedere il principio della nuova architettura.'

32. 'Voglio dirvi che ho un'assoluta certezza nelle forze dello spirito e dell'intelligenza italiana'.

33. Articles specifically on literature became less frequent after the first few issues, because Bardi and Bontempelli had become the directors of L'Italia Letteraria, which targeted the same audience as Quadrante, but had a more specifically literary focus (Mariani 1989, 241-42).

34. The fifth Triennial Exhibition of Modern Decorative Arts, Industrial Arts and Architecture was held in Milan in 1933. It was the first one to be held in the newly built Palazzo dell'Arte, designed by Giovanni Muzio.

35. '[...] L'architettura rappresentativa della nostra epoca è l'architettura delle case economiche, delle caserme, dei sanatori, delle case del Fascio, degli Istituti del Regime'.

36. 'Anche con le esposizioni d'architettura e d'arte decorativa bisogna andare verso il popolo'

37. ' [... la migliore letteratura italiana sta rivelando degni sforzi nella ricerca d'una superiore semplicità quanto ai mezzi, d'una profonda elementarità quanto alla sostanza'.

38. 'Dal Fascio alla Croporazione, il cittadino dello Stato Fascista sarà totalmente impegnato, nella sua fede e nel suo interesse, nella sua coscienza e nella sua professione, da una regola superiore d'ordine e d'unità [...]'.

39. '[...] un moto [...] diffuso nell'atmosfera morale del nostro tempo a operarvi una vasta revisione di valori e di principi'. 
Open Access This chapter is licensed under the terms of the Creative Commons Attribution 4.0 International License (http://creativecommons.org/ licenses/by/4.0/), which permits use, sharing, adaptation, distribution and reproduction in any medium or format, as long as you give appropriate credit to the original author(s) and the source, provide a link to the Creative Commons licence and indicate if changes were made.

The images or other third party material in this chapter are included in the chapter's Creative Commons licence, unless indicated otherwise in a credit line to the material. If material is not included in the chapter's Creative Commons licence and your intended use is not permitted by statutory regulation or exceeds the permitted use, you will need to obtain permission directly from the copyright holder.

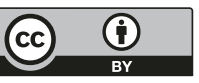

